\title{
Modernisering van medische opleidingen en het gebruik van richtlijnen
}

\section{Beweging}

Medische onderwijscurricula zijn de laatste jaren flink in beweging. Voor de Nederlandse opleidingen geneeskunde is een nieuw raamplan geschreven en voor de specialistenopleidingen zijn nieuwe curricula ontwikkeld. De effecten van deze beleidsdocumenten op de medische opleidingen krijgen steeds meer het karakter van een revolutie en een korte beschrijving van wat er op de klinische opleidingswerkvloer gebeurt, levert een bijna futuristische ervaring op.

\section{Heden of nabije toekomst: een beeld}

Naast de doorvoering van competentiegericht onderwijs, gebaseerd op zeven aan de CanMEDS rollen ontleende algemene competenties (medisch handelen, wetenschap, communicatie, samenwerking, organisatie, maatschappelijk handelen en professionaliteit), worden er vanuit de onderwijskunde nieuwe inzichten en methoden geïntroduceerd. Op het terrein van onderwijs en opleiding wordt veel energie gestoken in het transparanter maken van wat we voor de vorming van de arts van de nabije toekomst aan ingrediënten nodig hebben. De titel "Hoe bak ik een specialist" van een recent KNMG-congres getuigt daar van. Daarnaast wordt flink geïnvesteerd in de opbouw van geschikte toetsprogramma's. De norm is nu een combinatie van kennistoetsing, begrip en integratietoetsing, toetsing van simulatieoefeningen, observaties van handelen in de praktijk, gebruik van feedback uit diverse bronnen op de werkvloer en het als bron van informatie inzetten van ervarin- gen, gedocumenteerd in logboeken. Reflectie op het eigen leerproces en het gebruik van het portfolio als documentatie voor voortgangsgesprekken zijn niet meer weg te denken uit de praktijkgebonden medische opleidingen. Weloverwogen stapsgewijze toename van verantwoordelijkheid op de werkvloer wordt vastgelegd in bekwaamverklaringen, als een 'output' van het leerproces. Kwaliteitszorg neemt een grote vlucht. Docenten worden didactisch getraind, onderwijsinstituten en leerhuizen geven opleidingsmanagement vorm in de kliniek en kwaliteitscycli op basis van metingen als D-RECT, Set-Q en EFFECT worden ziekenhuisbreed ingezet. Opleidingsafdelingen maken hun kwaliteit zichtbaar in de 'opleidingsetalage' en doen aan gereguleerde marktwerking mee.

\section{Beweging gaat door}

Dit geschetste beeld wordt in een snel tempo realiteit. Vele enthousiaste docenten en onderwijskundigen hebben hard gewerkt om tot een indrukwekkende verbeterslag van de medische opleidingen te komen. Er zijn nog steeds veelbelovende ontwikkelingen gaande, waarover in het TMO steeds is te lezen, variërend van de verdieping van aspecten van de algemene competenties (zie Nuijten et al. over professioneel gedrag), tot maatschappijverkenningen (die Custers als in Franstalige gebieden opvallend gepositioneerd beschrijft), tot inzet van 'blended learning' (zie Bos et al.) en zelfs 'serious gaming' waaraan onze zustervereniging Dutch Society for Simulation in Healthcare (DSSH) haar jaarcongres heeft gewijd. 


\section{Criticasters hebben behoefte aan snel toegankelijke 'evidence'}

Deze revolutie in het medisch onderwijs kost zeer veel energie en geld en criticasters stellen graag vragen over het nut. "Wat is nu eigenlijk de 'evidence' voor al deze ontwikkelingen?" is voor menige leider bij de modernisering van onderwijs en opleiding een al te bekende vraag. Het opleiden van aios in de kliniek doet mij vaak aan patiëntenzorg denken. Je baseert je bij patiëntenzorg op beschikbare kennis en handelt vervolgens in wijsheid, rekening houdend met contextuele factoren en eigenschappen van de individuele patiënt in kwestie. De beschikbare kennis is meestal samengebracht in richtlijnen waarin deels op basis van wetenschappelijk bewijs en deels op consensus gebaseerd, beleidsadviezen gegeven worden. Richtlijnen zijn vaak opvallend verschillend tussen diverse culturen. Verder zijn richtlijnen passend bij de tijd waarin we leven en bij het welvaartsniveau. Over 10 of 20 jaar is een richtlijn mogelijk achterhaald. Criticasters die de modernisering ter discussie stellen, hebben de neiging strengere eisen bij de onderbouwing van een moderne opleiding te hanteren dan bij de onderbouwing van hun eigen medische beleid. Dat laat echter onverlet dat wij de onderbouwing voor onderwijsme- thoden en instrumenten zo goed mogelijk ter beschikking moeten stellen.

\section{In VIVO Richtlijnen}

Binnen het project 'In VIVO' waarbij Kindergeneeskunde en Obstetrie \& Gynaecologie hun gemoderniseerde specialistenopleidingen als 'pilot' in de praktijk brachten, bleek dat opleiders en aios behoefte hadden aan toegankelijke richtlijnen over opleiden. De 'AMEE guidelines' waren lang niet voor iedereen voldoende geschikt. Onderwijskundigen en clinici bogen zich over de onderwerpen en gingen gezamenlijk aan de slag. Het werd een pretentieus project om in samenwerking met de NVMO tot 'In VIVO Richtlijnen' te komen die een bron zouden vormen voor een op beschikbare 'evidence' gebaseerde discussie en beleidskeuze. Het TMO geeft de Richtlijnen, die zijn goedgekeurd door de NVMO Reviewcommissie Richtlijnen, als supplementen uit. We hopen dat er veel discussie uit voortkomt en dat de ervaring van de komende jaren tot nieuwe verbeterde versies zal leiden. Dit jaar kunt $\mathrm{u}$ er een tiental verwachten. Wij wensen $\mathrm{u}$ veel leesplezier en boeiende discussies toe!

Fedde Scheele 